\title{
THE ROLE OF POLAR DEEP WATER FORMATION IN GLOBAL CLIMATE CHANGE
}

\section{William W. Hay}

GEOMAR, Christian-Albrechts-Universität, D-2300 Kiel 14, Germany, and Department of Geological Scicnces, CIRES and Museum, University of Colorado, Boulder, Colorado 80309

KEY WORDS: Arctic, Antarctic, palaeoceanography

\section{INTRODUCTION}

The present ocean is thermally stratified. The waters become colder with depth, and the great mass of ocean deep water is near $2^{\circ} \mathrm{C}$-almost the same as that of surface waters in the polar regions. The idea that the waters have a polar origin goes back to Benjamin Thompson (1800) (Count Rumford). He reasoned that the cold waters of the interior of the ocean must form by sinking in the polar regions and must drive poleward flow of surface waters. The idea was refined by Alexander von Humboldt (1814), who noted that the density of sinking cold polar waters must exceed the density of more saline waters in lower latitudes.

The first person to have seriously questioned the assumption that the deep waters of the ocean have always been cold and hence formed in the polar regions was T. C. Chamberlin (1906), who suggested that salinity rather than thermal differences may have driven the ocean.

The first direct evidence that ocean deep waters might have been significantly different in the past was provided by Emiliani \& Edwards (1953) and Emiliani (1954). They noted that Tertiary deep water temperatures recorded by oxygen isotopes in the shells of benthic foraminifers from the Pacific were significantly warmer $\left(10.5^{\circ} \mathrm{C}\right)$ than that of the deep waters at present $\left(1.75^{\circ} \mathrm{C}\right)$. They suggested that this indicated warmer polar seas in the past. 
Henry Stommel (1961) quantified the argument that both temperature and salinity differences might be driving mechanisms for ocean convection. He concluded that the thermohaline convection of the ocean has two stable regimes of flow, one in which the temperature differences dominate the density differences, and the other where salinity dominates the density differences.

Claes Rooth (1982, p. 132) discussed the climatic consequences of a change in polar deep water formation. He noted that "the most cursory examination of any oceanographic atlas or standard textbook quickly establishes an awareness of temperature as the predominant factor controlling oceanic density stratification. That such should be the case is intuitively appealing in view of the large range of climatic conditions on the surface of the earth, but on closer examination, the inevitability of this state of affairs is not at all self-evident." Rooth introduced several new ideas. He noted that thermal anomalies of the sea surfacc causc changes in both the latent and sensible transfer of heat between the ocean and atmosphere. Because the water content of saturated air doubles with every $10^{\circ} \mathrm{C}$ temperature increase, the evaporation is important in modifying the surface water masses in the tropics, but its effects are dominated by those of the meridional temperature gradient. The effect of the excess of rainfall and runoff over evaporation at high latitudes resulting from the import of water from humid lower latitudes, is to locally freshen the surface of the ocean. In the polar regions, where the temperature of the water is everywhere about the same, salinity effects dominate. "A dominance of salt effects would in fact almost certainly be hypothesized by a land-bound naturalist with access only to observations from estuaries and from warm hypersaline tropical lagoons..." (p. 133). Rooth noted that although the driving force for the main ocean gyres is wind stress, the circulation of the ocean is not global. Rather, it is broken up into basin-wide gyres which lie between the extremes of zonal wind stress and the equator. In the present thermally stratified ocean, the effect of the wind stress is concentrated in the surface mixed layer. In the absence of other forces, this would mean that poleward heat transport in the oceans would not extend beyond $45^{\circ} \mathrm{N}$ and $\mathrm{S}$ latitude. It is the thermohaline circulation that allows the ocean heat transport to extend to higher latitudes. On the basis of data presented by Lazier (1973 and later personal communications), Rooth discussed the sensitivity of the deep water production in the Labrador Sea to changing salinities in the North Atlantic. He concluded that the deep water production in the North Atlantic is delicately balanced, and can be shut down by relatively small changes in the fresh-water balance. Most significantly, he observes that if the thermohaline circulation were to slow down significantly, changes in the hydrology at high latitudes would have a positive 
feedback effect, producing a sub-polar halocline which would make it more difficult to restart the thermohaline circulation.

The atmosphere and ocean transport heat from the equatorial to the polar regions. The ocean presently accounts for about $2 / 3$ of poleward flux of energy in the tropics. In the subtropics, the ocean accounts for about $1 / 2$ of the poleward energy flux. Between the subtropical and polar convergences, oceanic energy transport declines, and beyond the polar convergences (about $60^{\circ} \mathrm{N}$ and $\mathrm{S}$ ) poleward energy transport by the ocean is negligible. The role of the ocean in poleward energy transport is limited by the presence of oceanic convergences along which waters sink, interrupting the poleward flow. The rate at which polar waters sink is a major factor in determining the rate at which tropical-subtropical waters are advected to high latitudes.

Hsiung (1985) has shown that the meridional heat transport in the different ocean basins is remarkably different. As shown in Figure 1, heat is transported northward throughout the Atlantic and southward throughout the Indian Ocean. In the Pacific Ocean, heat is transported northward north of $5^{\circ} \mathrm{S}$. These differences are to a large extent determined by the presence of sites of formation of ocean deep waters in the Antarctic and North Atlantic.

\section{FORMATION OF OCEAN DEEP WATER}

Stommel(1962) noted that although the thermohaline vertical circulation of the ocean is one of its major features, the sites of sinking of ocean deep waters are quite small. The thermohaline circulation is driven by formation of dense water in small regions where isolation and transformation of the water masses can occur. These small areas are shown in Figures 2 and 3.

Peterson (1979) modeled the sinking of dense plumes and concluded that it is the buoyancy flux, defined as the product of the excess density times the volume flux, that determines whether a given source will produce ocean bottom water. The plume with the highest buoyancy flux fills the ocean from below; plumes with a lesser buoyancy flux produce intermediate waters that are recycled more rapidly to the surface.

Killworth (1983) has summarized the processes by which waters sink to become part of the deep convection system of the ocean. He distinguished two types of formation of deep water: that which takes place near ocean boundaries and that which occurs in the open ocean.

\section{Deep Water Formation Near an Ocean Boundary}

For deep water formation near an ocean boundary, Killworth (1983) cited five requirements: a reservoir, a source of dense water within the reservoir, 
Meridional Heat Transport

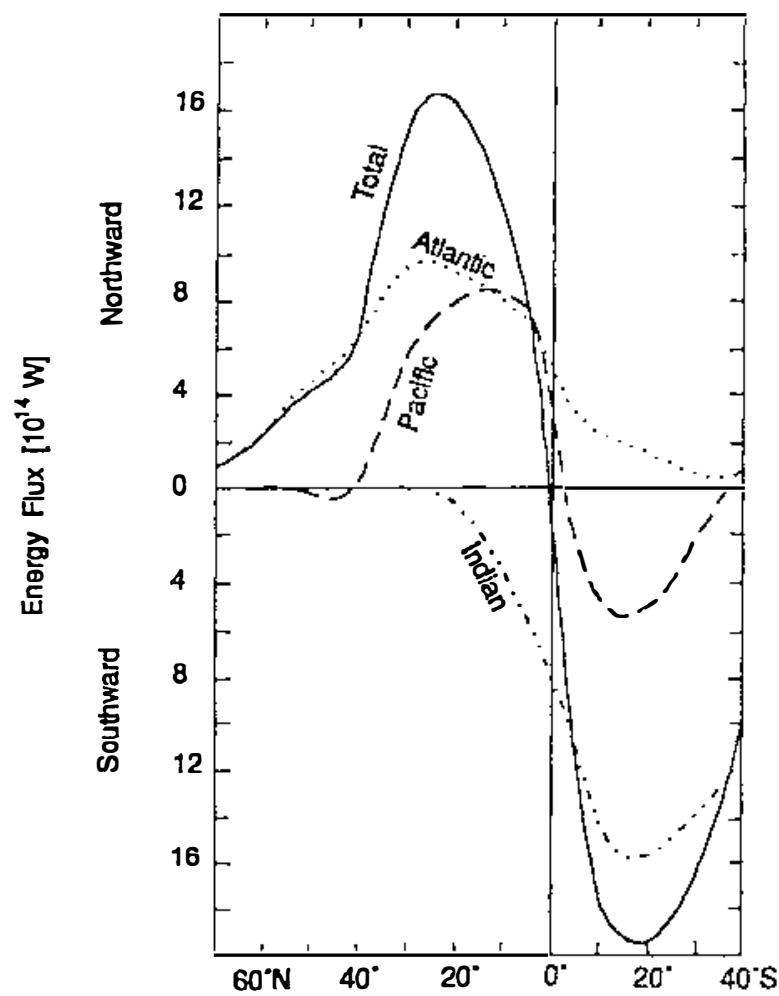

\section{Latitude}

Figure 1 Meridional heat transport in the oceans (after Hsiung 1985).

a reason for the dense water to leave the reservoir, that more than one water mass be involved, and lastly, that no obstructions prevent the dense water from reaching the ocean bottom.

A reservoir is a restricted site within which the water can be maintained and modified. The continental shelf is such a site, and the wider the shelf the better it is as a site for transformation of ocean waters. Shallow shelf seas may also serve as appropriate sites. The shelf or shallow sea must 


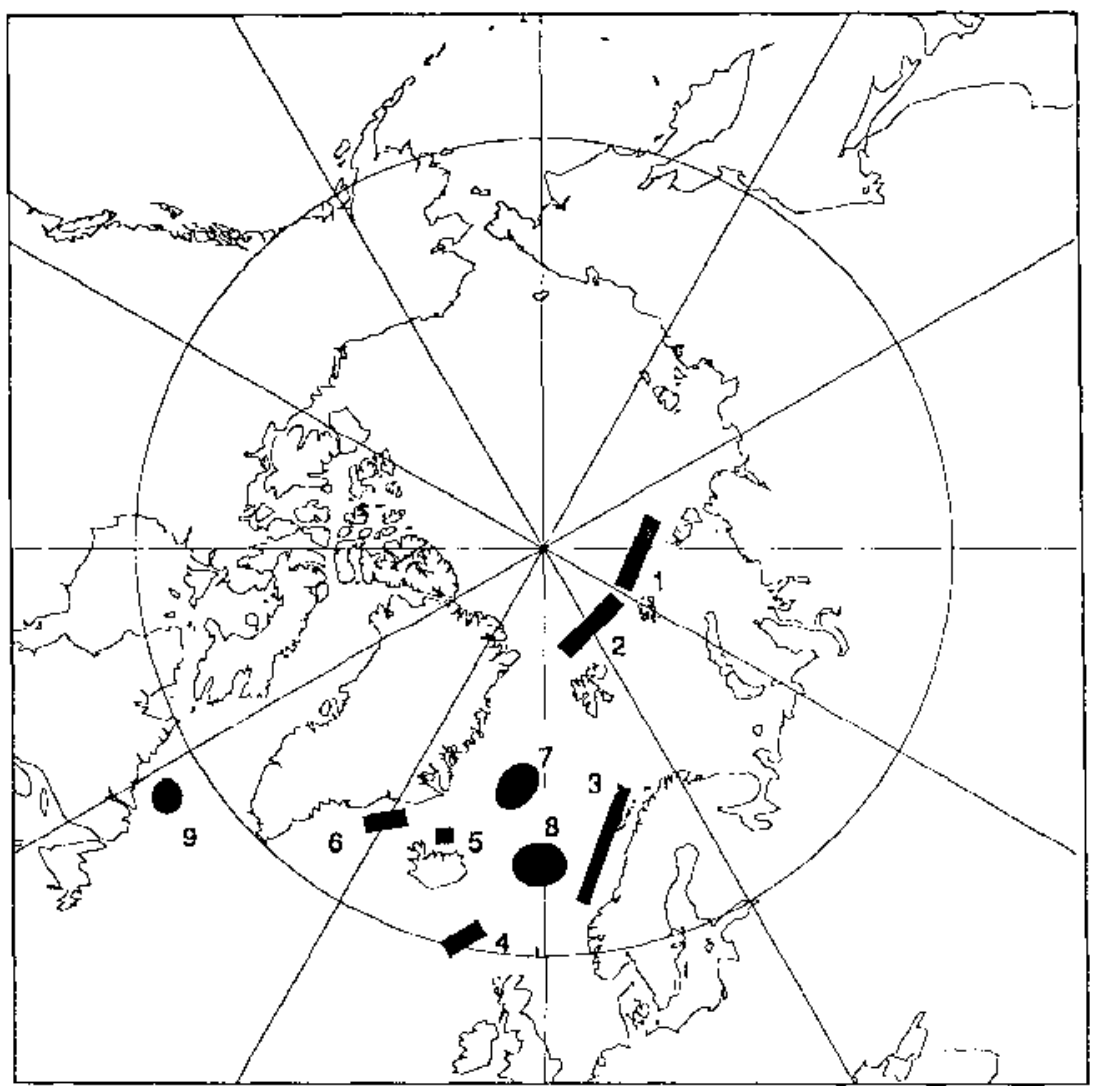

Figure 2 Sites of deep water formation in the northern hcmispherc (after Killworth 1983). Rectangles are sites near the ocean boundary: (I) Kara Sea shelf, (2) Barents Sea shelf, (3) Norwegian Sea shelf, (4) Iceland-Scotland Ridge, (5) Icelandic shelf, (6) Greenland shelf. Ellipses are open ocean sites: (7) Greenland Sea, (8) Norwegian Sea, (9) Labrador Sea. The Iceland Shelf and Labrador Sea sites are the main contributors to North Atlantic Deep Water formation.

either have a negative or negligible fresh water balance (evaporation $>$ precipitation + runoff). Most of the Arctic shelves have a positive fresh water balance and are well supplied with runoff so that they cannot become sites of decp water formation. The shelves surrounding the ice-covered Antarctic, with a negligible fresh water balance and receiving no runoff, have a much greater potential to be sites of deep water formation.

Within the reservoir dense water forms mostly through air-sea inter- 


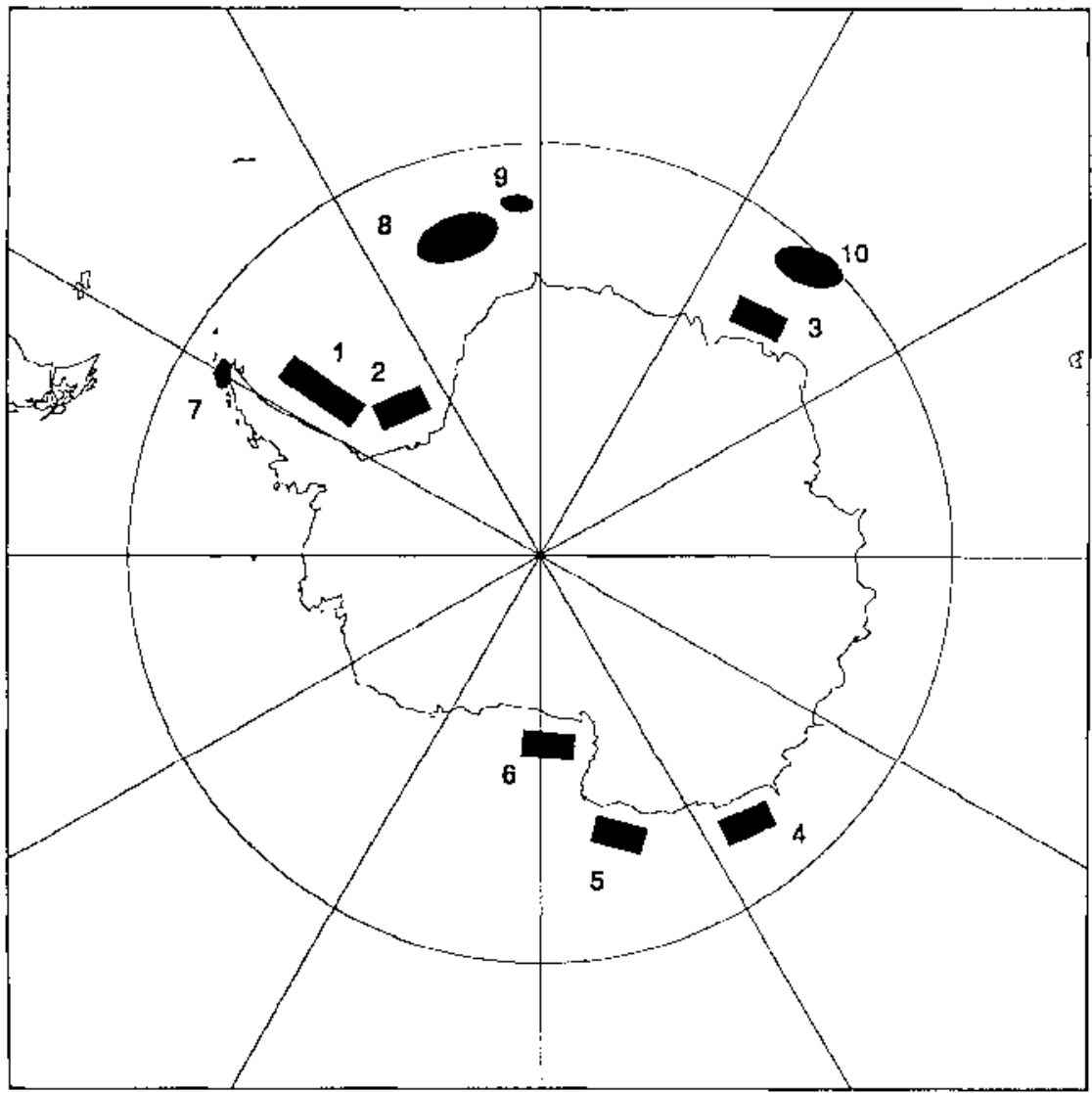

Figure 3 Sites of decp watcr formation in the southern hemisphere (after Killworth 1983). Rectangles are sites near the ocean boundary: (1) Weddell Sea shelf along the Antarctic Peninsula, (2) Weddell Sea shelf in front of Ronne and Filchner Ice Shelves, (3) off Enderby Land, (4) off Wilkes Land, (5) off Adélie Land, (6) Ross Sea shelf. Ellipses are open ocean sites: (7) Bransfield Strait, (8) Weddell Polynya above Maude Rise, (9) site of Weddell Sea chimneys reported by Gordon (1978), (10) off Enderby Land. The Weddell Sea sites are the main contributors to Antarctic Bottom Water formation.

action: cooling by conduction, cooling by evaporation, increase of salinity by evaporation, and increase of salinity by formation of sea ice. As suggested by Brennecke (1921) and Mosby (1934), the main mechanism for increasing the density of sea water in the polar regions today, is freezing of sea ice. Sea ice has a salinity $<6 \%$ compared with the minimum salinity of polar waters of $27.4 \%$ (Gow \& Tucker 1990).

The reason for dense water to leave the reservoir and descend to the 
ocean floor is not always obvious. Mosby (1934) assumed that as the waters in the reservoir became more dense than those of the surrounding ocean, gravity would pull them down the slope to the deep ocean floor. However, as the dense waters begin to move they are acted upon by the Coriolis force and soon a geostrophic balance is attained between the downslope buoyancy force and an upslope Coriolis force so that the water would tend to move along depth contours rather than descend into the basin (Killworth 1977). Killworth (1983) suggested that a necessary prerequisite for dense water to leave a reservoir and descend to the ocean floor is preexisting circulation that can drive it off the shelf. Another possibility is that turbulent friction of flow along the bottom may act as a third force to destroy the geostrophic balance. Another possible factor is the greater compressibility of cold water: the density of descending cold water can increase faster than that of the surrounding warmer water, thus destroying the geostrophic balance.

In the present day oceans formation of deep water always involves more than one water mass. The process of caballing - the formation of denser water by mixing of waters of equal density but different temperature and salinity characteristics - may be important. Because bottom flows are inherently turbulent and must involve entrainment of the surrounding waters, their density must always decrease after leaving the site where they were modified by air-sea interaction.

The last factor discussed by Killworth is the lack of obstructions, such as sills and othcr topographic features, which might trap the dense waters and prevent them from reaching the deep seafloor.

Killworth (1983) lists the following as sites where deep water formation takes place near an ocean boundary: 1. the western Weddell Sea, 2. the Ross Sea, 3. the Adélie Coast and Enderby Land, 4. Wilkes Land, 5. the Arctic, 6. the Norwegian, Greenland, and Iceland shelves, 7. the Adriatic, 8. the shelf of the Gulf of Lions, 9. the Gulf of Suez, and 10. the Persian Gulf. The first six of these are polar sites of cold water formation; the last four are subtropical.

THE ANTARCTIC SITES The Weddell Sea was identified by Mosby (1934) as the most important site of deep water formation today. It produces the bulk of the $\pm 38 \mathrm{~Sv}\left(1 \mathrm{~Sv}=10^{6} \mathrm{~m}^{3} \mathrm{~s}^{-1}\right)$ of Antarctic Bottom Water (AABW) that enters the deep Atlantic, Indian, and Pacific Oceans. The Weddell Sea has a narrow $(<90 \mathrm{~km})$ eastern shelf, a broad $(>400 \mathrm{~km})$ shelf off the Filchner and Ronne Ice Shelves, and a $200 \mathrm{~km}$ wide shelf off the Antarctic (Palmer) Peninsula. Although these shelves occupy $25 \%$ of the $2.3 \times 10^{6} \mathrm{~km}^{2}$ area of the Weddell Sea, the water over them is only $4 \%$ of the $7.6 \times 10^{6} \mathrm{~km}^{3}$ volume of the basin. The surface water layer develops 
a thickness of $50 \mathrm{~m}$ in the summer and has a variety of temperatures $\left(-2^{\circ}\right.$ to $1^{\circ}$ ) and salinities $(<34.4 \%$ ). It is underlain by Winter Water (WW); a halocline separates the less saline surface water from the saltier WW $\left(-1.8^{\circ} \mathrm{C}, 34.4 \%\right)$. The WW overlies Warm Deep Water (WDW) which here typically has temperatures of $0^{\circ}$ to $0.8^{\circ}$ and salinities of $34.6-34.7 \%$. The two water masses are separated by an intermediate layer of Modified Warm Deep Water (MWDW). The base of the WDW lies at a depth of $1000-2000 \mathrm{~m}$. The bulk of the basin $(60 \%)$ is filled with Antarctic Bottom Water (AABW: $0^{\circ}$ to $-0.8^{\circ} \mathrm{C}, 34.6-34.7 \%$ ). The coldest and densest water in the basin is Weddell Sea Bottom Water (WSBW) $\left(-1.4^{\circ}\right.$ to $-0.8^{\circ}$, $34.65 \%$ ) which occurs on the slopes and southern and western edges of the basin (Gill 1973, Carmack \& Foster 1977).

The formation of AABW has been discussed by Gill (1973), Foster \& Carmack (1977), Killworth (1977, 1983), and Carmack (1990). Mosby (1934) assumed that the driving mechanism was formation of sea ice over the shelf in the winter. Fofonoff (1956) and Foster (1972) suggested that caballing at the shelf edge played a major role. Seabrooke et al (1971) proposed that freezing of seawater onto the bottom of the ice shelves is significant in increasing the salinity of the shelf waters. Gill (1973) noted that the Antarctic Coastal Current flows as a ribbon of fresher water along the edge of the shelf, separating the saline shelf water from the Weddell Sea surface water along a V-shaped front (Figure 4). At the base of the front, the cold, saline shelf waters mix with warmer, fresher MWDW and flow down the slope into the deep basin at a rate of about $1 \mathrm{~Sv}$. He also emphasized that the pack ice is continually being blown offshore, presenting fresh open water surface for the formation of new sea ice. The annual brine release equals the freezing of $1 \mathrm{~m}$ or more of ice. Foster \& Carmack (1976) described the interleaving of shelf waters with MWDW in the southern and southwestern shelves, and noted the presence of a thin layer of cold WSBW on the adjacent continental slopes. They argue that it is the mixing of the shelf and MWDW waters that produces WSBW, which then flows clockwise around the basin entraining WDW to form AABW. Killworth noted that the onshore Ekman transport driven by the easterly winds produces fluxes of $1-1.5 \mathrm{~Sv}$ and is an important factor in setting conditions for sinking.

Warren (1981) suggested that the water entrained by outflow from the Ross Sea shelf is warmer and more saline than that entrained by Weddell Sea shelf water at the shelf break. Because of these differences the Ross Sea may be a minor contributor to AABW.

Around much of the Antarctic margin there is a depression between the coast and the shelf break. The weight of the Antarctic ice shcet has depressed the continent and inner shelf so that there is an upward slope 


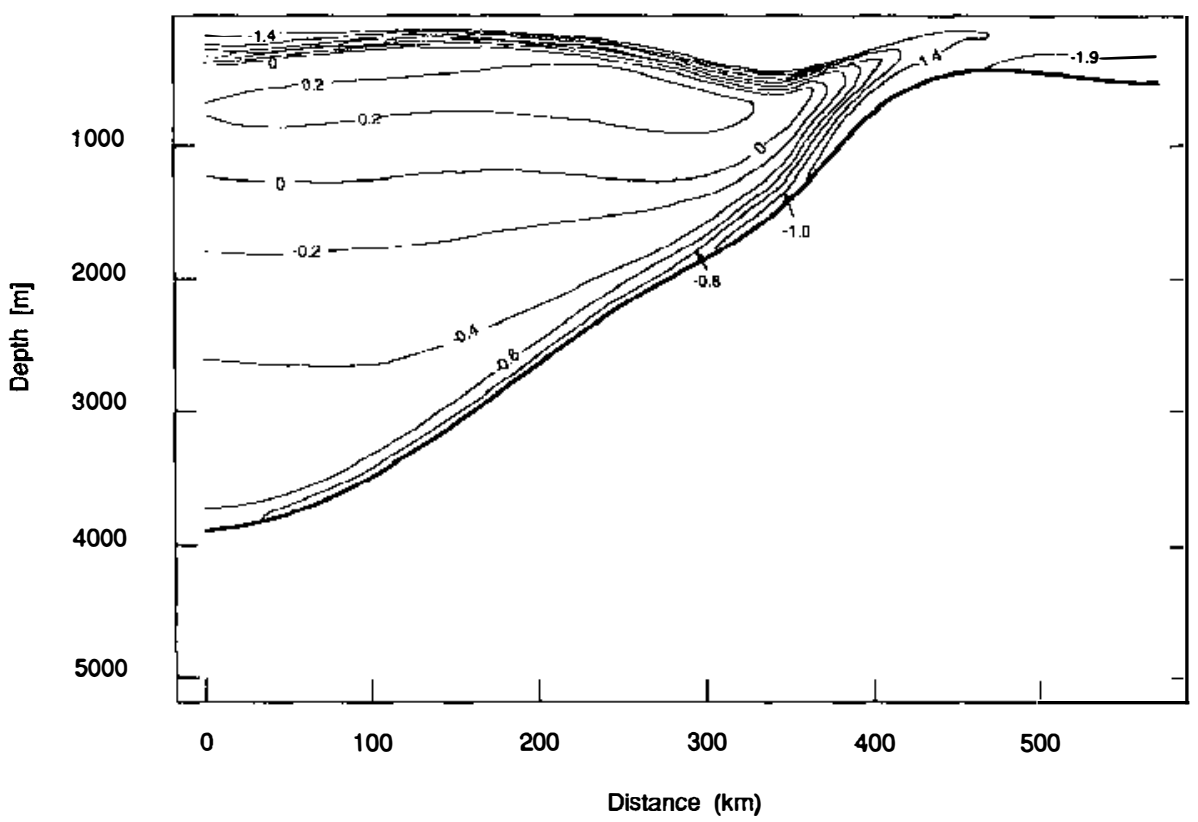

Figure 4 Potential temperature section across the shelf break in the Weddell Sea near $51^{\circ} \mathrm{W}$ showing a tongue of Modified Warm Deep Water interleaving with cold waters in front of the Ronne Ice Shelf (after Foster \& Carmack 1977).

to the shelf break at about $400 \mathrm{~m}$. This situation is well developed off the Adćlie Coast (Gordon \& Tchornia 1972) and Enderby Land (Jacobs \& Georgi 1977). In these places the shelf depressions act as reservoirs for saline shelf water, but these are small compared with the Weddell and Ross Sea shelves. Their contribution to AABW is probably small.

Off Wilkes Land, just west of the Ross Sea, a plume of cold water descends the slope, but does not reach the bottom and spreads horizontally at $2000 \mathrm{~m}$ (Carmack \& Killworth 1978). The plume lacks the salinity required to be dense enough to reach the bottom. Killworth (1983) suggested that similar processes may go on around much of the Antarctic margin.

THE ARCTIC SITES Significantly, the Earth's only truly polar ocean, the Arctic Ocean, is not a site of formation of deep watcr that enters the world's oceans (Coachman \& Aagaard 1974). In contrast to the ocean surrounding Antarctica, the Arctic Ocean has an extensive perennial sea ice cover. The surface layer is termed Arctic Water, and can be divided into surface, subsurface, and lower layers. Arctic Surface Water is up to 
$50 \mathrm{~m}$ thick. Because of the perennial sea ice cover, the temperatures are always about freezing - from $-1.5^{\circ}$ to $-1.8^{\circ} \mathrm{C}$. Salinities range from $28 \%$ to $33.5 \%$ (Pickard \& Emery 1990). The higher salinitics lie off the Barents shelf, and decrease toward the Bering Strait. The Arctic Subsurface layer extends to $150 \mathrm{~m}$ and has a strong halocline, with salinities increasing to $34 \%$. The Arctic Lower layer extends to $200 \mathrm{~m}$ and is the transition to the underlying Atlantic Water. The low salinity surface layer of the Arctic Ocean results from melting sea ice and the large volume of river runoff during the summer. The runoff into the Arctic Basin, estimated by Alyushinskaya \& Ivanov (1978) to be $5220 \mathrm{~km}^{3} \mathrm{yr}^{-1}$, is equivalent to a $35 \mathrm{~cm}$ layer. It effectivcly prevents any large-scale deep water formation.

Beneath the Arctic Water lies Atlantic Water, which enters from the Norwegian Sea as the West Spitsbergen Current. It has a temperature of $1^{\circ}$ to $0.4^{\circ} \mathrm{C}$ and salinites between $34.8 \%$ and $35.0 \%$. It flows along the Eurasian Margin and spreads across the Lomonosov Ridge into the Canadian Basin. On the Eurasian Margin it is introduced via submarine canyons onto the shelf, where it can be modified (Aagaard et al 1985).

Below $800 \mathrm{~m}$ the Arctic Ocean is filled with Arctic Bottom Water (ABW), with potential temperatures of $0.4^{\circ}$ to $-0.8^{\circ} \mathrm{C}$ and salinities between 34.90 and $34.99 \%$ (Pickard \& Emery 1990). Aagaard et al (1985) suggest that ABW is a mixture of waters from four sources: Greenland Sea Deep Water (GSDW), Norwegian Sea Deep Water (NSDW), Eurasian Basin Deep Water (EBDW), and Canadian Basin Deep Water (CBDW). As discussed below, GSDW and NSDW are formed in the Greenland-Iceland-Norwegian (GIN) Seas. They are introduced into the Arctic Basin through Fram Strait. EBDW and CBDW which form at sites on the Arctic shelves away from the influence of major rivers may also be from sites of generation of saline shelf waters through brine expulsion resulting from the freezing of sea ice (Aagaard 1981, Melling \& Lewis 1982). The saline shelf waters do not descend into the deep but spread laterally beneath the cold fresher surface water, contributing to the development of the Arctic Ocean halocline at $250 \mathrm{~m}$. The rate of formation of saline shelf waters is estimated by these authors to be about $2.5 \mathrm{~Sv}$.

It is likely that dense cold saline waters also form on the shelves surrounding the GIN Sea.

\section{Deep Water Formation in the Open Ocean}

For deep waters to form in the open ocean Killworth (1983) also cites five requirements: 1 . background cyclonic circulation, 2 . preconditioned gyre waters, 3 . intense surface forcing, 4 . the involvement of more than one water mass, and 5. breakup of the convective structure, with sinking and spreading of the transformed water mass. He cites the following areas as 
examples of regions where open ocean convection occurs: the Labrador Sea, the Bransfield Strait, the Weddell Sea, the Greenland Sea, and the Mediterranean.

Cyclonic circulation means that the waters in the center of the gyre are moving upward. At first this might seem to be contradictory to sinking, but the dynamics of the upward motion induced in the gyre center bring denser waters closer to the surface, reducing the intensity of wind forcing required for upwelling to occur. The upward doming of the isopycnals also reduces the vertical stability or stratification in the centers of the gyres.

Preconditioning is a modification of the surface waters over a period of weeks to a few months that further reduces the vertical stability of the water. The preconditioning is usually a result of atmospheric interactions. Cyclonic eddies superposed on the cyclonic circulation can further weaken the stability, as has been described by Clarke \& Gascard (1983) in the Labrador Sea. Wind-driven upwelling might serve to precondition the water. It is also possible that the submarine topography may precondition the water by affecting the gyral circulation. This has been proposed by Hogg (1973) to explain the reduction in stratification in the Gulf of Lions above the Rhone Fan. Development of a polynya, an open water area that forms in the midst of sea ice, also preconditions the water, but the cause of polynyas remains uncertain. Gordon (1982) has cited submarine topography (the Weddell Polynya seems to form consistently above Maud Rise), reduced precipitation, increase in ice formation, an increase in the flux of deep saline water, and a shift in the position of the Weddell Sea gyre as possible causes.

Deep water formation in the open ocean always involves more than one water mass. The different water masses initially provide stability, but thermal stabilization can bc overcomc by cooling and salinity stabilization can be overcome by cooling or salinization of the fresher water through sea ice formation. Killworth (1979) noted that the greater compressibility of cold water may allow surface forcing to mix down waters that are neutrally buoyant at the surface but become more dense than the surrounding waters at depth. The initial effect would be a gradual increase in the thickness of the mixed layer until the lower layer is reached. Then the depth of mixing might increase rapidly to depths of $2000 \mathrm{~m}$ or more.

Intense surface forcing occurs over a period of days to weeks. Very cold winds blowing over warmer waters chill the water both by sensible and latent heat loss. Brine ejection from freezing sea ice can be another form of intense surface forcing.

The surface forcing results in an episode of violent vertical mixing. This occurs within a vertical chimney - an unstable convective feature a few tens of kilometers across in which large convective fluxes can occur. The 
chimney is associated with cyclonic circulation set up in the surface waters and presumed to be also present at depth. Within the chimney waters can flow to depth and be replaced by deep waters without being stopped by a pycnocline.

Convection stops with breakup of the chimney structure and the development of vertical stability. The transformed water masses that sank through the chimney spread in the deep sea, ending the episode of open ocean convection. Relics of the chimney may persist for months.

THE ANTARCTIC SITES Two kinds of open ocean convection have been described from the Weddell Sea. The general circulation of the Weddell Sea is cyclonic. Gordon (1978) described a cyclonic eddy containing a central chimney about $30 \mathrm{~km}$ in diameter (Figure 5). Although when observed it was vertically stable, it was clearly a relic from the winter convection. Gordon estimated that up to 30 such chimneys might develop in the Weddell gyre each year, and that they might be responsible for deep water production at a rate of $0.6 \mathrm{~Sv}$. The Weddell Polynya, which forms over Maud Rise on the east side of the gyre, has been present during many winters. Martinson et al (1981) have suggested that the freezing of sea ice adjacent to the polynya results in a downward flux of saline water at a rate of $1 \mathrm{~Sv}$ causing overturning and bringing $0^{\circ}$ watcr to the surface. Gordon (1982) has suggested average rates of flux of saline water from freezing of sea ice at 3.8-7.7 Sv during the wintertime.

The Bransfield Strait lies west of the tip of the Antarctic Peninsula, and is floored by three troughs ranging from 1100 to $2800 \mathrm{~m}$ in depth. It does not have an internal cyclonic circulation but does experience surface to boltom convection in the winter (Gordon \& Nowlin 1978). It contains a nearly homogeneous water mass of lower temperature and salinity and higher density than the surrounding waters. The water is trapped in the basins by relatively shallow sills.

THE ARCTIC SITES The Greenland Sea has a cyclonic circulation resulting in formation of a pycnocline dome located at $0^{\circ} \mathrm{E}$ and $75^{\circ} \mathrm{N}$. The dome contains water colder than $0^{\circ}$ and having a salinity of $34.9 \%$. The bottom water of the Greenland Sea is colder $\left(<-1^{\circ} \mathrm{C}\right)$. According to Peterson \& Rooth (1976) tritium measurements indicate that deep mixing must take place in the middle of the gyre. They estimated the time scale of deep convective mixing in the Greenland Sea to be about 30 years, implying that $100 \mathrm{~m}$ of surface waters are mixed down each year. Attempts to locate surfacc waters with the same temperature and salinity characteristics as the Greenland Sea bottom waters have failed, and hence the origin of the Greenland Sea bottom water remains uncertain. However, several interesting new ideas have recently been proposed. Reid (1979) has shown 


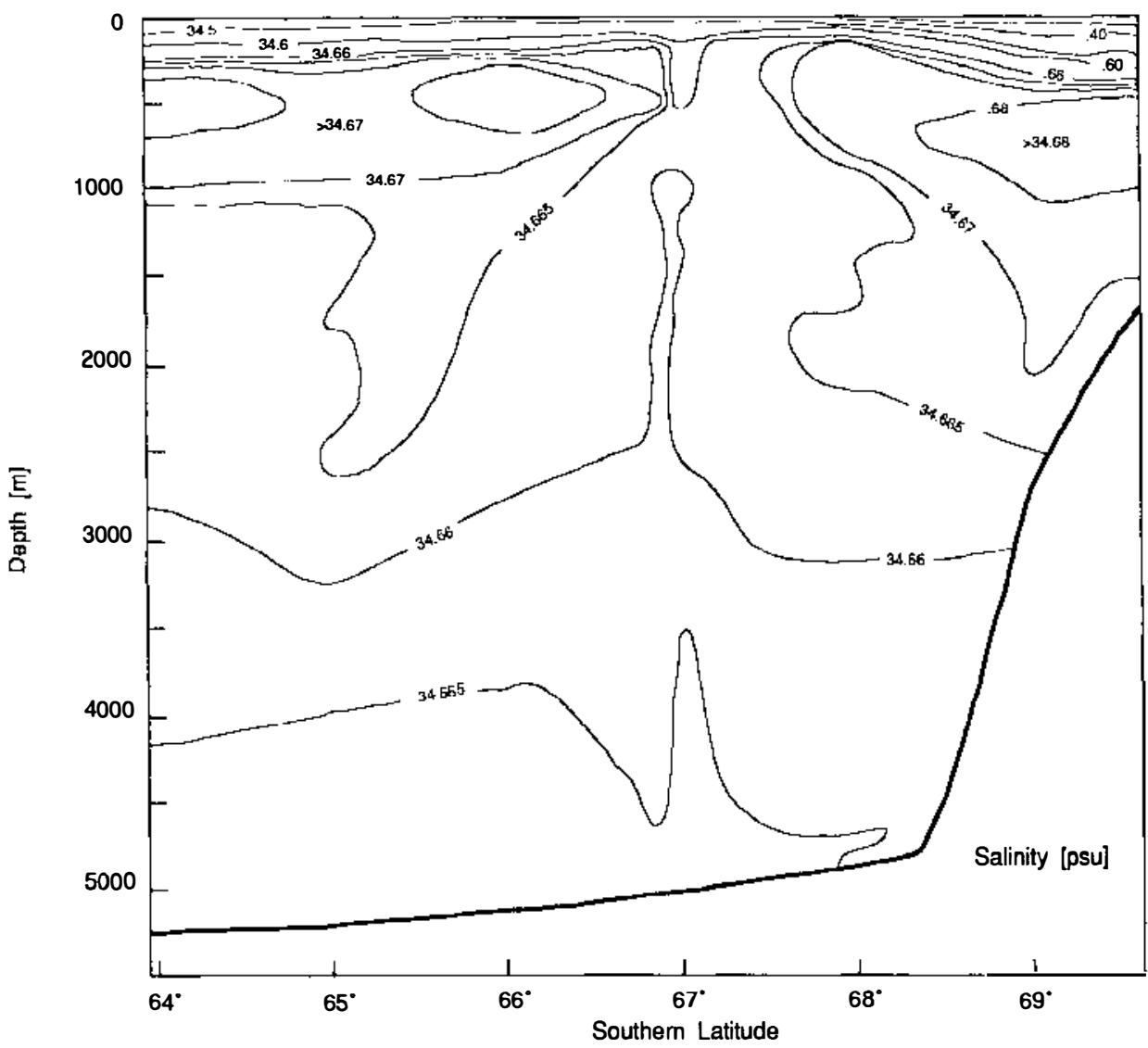

Figure 5 Salinity section northward f rom the Antarctic margin in the Weddell Gyre showing a "chimney" (after Gordon 1978).

that warm saline Mediterranean water that enters the Nordic Seas between the Faroes and Scotland may be advected westward to become a significant contributor to the water that sinks in the Greenland Sea. Hakkinen (1987) has noted that upwelling occurs in the ice marginal zone because of the larger drag coefficient of the ice, suggesting that the cooling of this upwelled water may produce deep water. Rudels (1989) has proposed that brine expulsion during the early stages of sea ice formation may create an unstable surface boundary layer which then sinks as a turbulent plume.

The deep waters of the Norwegian Sea are warmer, more saline, but slightly less dense than those of the Greenland Sea. Worthington (1970) 
suggested that the warm saline waters entering the Norwegian Sea are cooled without appreciable freshening. Reid (1979) showed that the higher salinity comes both from the North Atlantic Drift at the surface and modified Mediterranean outflow at depth. Peterson \& Rooth (1976) noted that the time scale of mixing of the Norwegian Sea is considerably longer (100 years) than that of the Greenland Sea.

The circulation in the Labrador Sea is also cyclonic. Clarke \& Gascard (1982) described a region of homogencous water $50 \mathrm{~km}$ wide and $2000 \mathrm{~m}$ deep, with internal eddies on a variety of scales down to $5 \mathrm{~km}$. It was suggested that the region of homogeneous water was an eddy generated by intensive heat loss $\left[480 \mathrm{~W} \mathrm{~m}^{-2}\right.$ according to a personal communication from J. C. Gascard cited by Killworth (1983)] which was caused by extremely cold, dry winds blowing off the ice cover of the northern Labrador Sea.

FORMATION OF NORTH ATLANTIC DEEP WATER North Atlantic Deep Water (NADW) is a mixture of water from several sources (Figure 6). Most of it originates in flows over the Greenland-Scotland Ridge (Meincke 1983). The densest water is contributed from the Greenland Sea via overflow of the Greenland-Iceland Ridge through the Denmark Strait as Denmark Strait Overflow Water (DSOW) with a potential temperature $1-2^{\circ} \mathrm{C}$ and a salinity of $34.9 \%$. Swift et al (1980) noted that the densest water above the sill is Norwegian Sea Deep Water $\left(<0^{\circ}, 34.9 \%\right.$ ), but that this contributes only $10 \%$ of the outflow. The major outflow is Arctic Intermediate Water formed north of Iceland during the winter. The Denmark Strait outflow is estimated at $4 \mathrm{~Sv}$ by Warren (1981). DSOW flows down the slope and along the eastern margin of south Greenland, entraining another $1 \mathrm{~Sv}$ of Atlantic water to form North-West Atlantic Bottom Water. Contributions from the Norwegian Sea flow through passages between Iceland and the Faroes and between the Faroes and Shetlands. This outflow is less dense than that from the Greenland Sea, and follows a tortuous route being held against the right-hand slopes by the Coriolis force. About $1 \mathrm{~Sv}$ of water passes through the Faroes Bank Channel, with a sill depth of about $850 \mathrm{~m}$ (Warren 1981). Some of it flows down and south along the eastern margin of Rockall Bank, entraining another $4 \mathrm{~Sv}$ to become NorthEast Atlantic Deep Water (NEADW). Turning north along the west side of Hatton Bank, it reaches the south side of Iceland-Faroes Ridge. There it is joined by $1 \mathrm{~Sv}$ of water flowing over the shallower $(400 \mathrm{~m})$ ridge between Iceland and the Faroes (Warren 1981). These waters entrain another $3 \mathrm{~Sv}$ as they flow south again along Rekjanes Ridge. At $52^{\circ} \mathrm{N}$ they turn west to flow through the Charlie Gibbs fracture zone into the western basin. There they override and mix with the water from the Denmark 


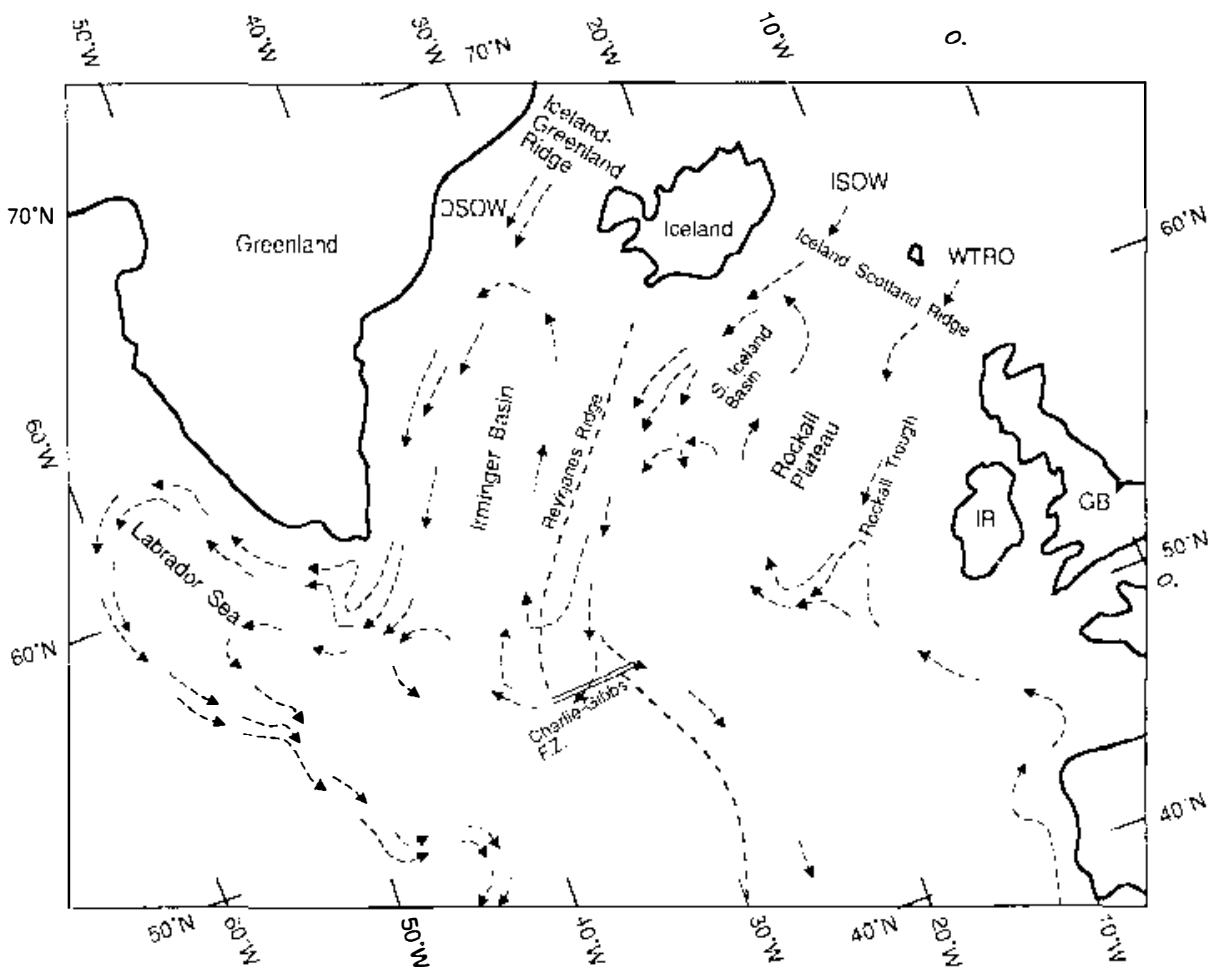

Figure 6 Deep waters in the North Atlantic, showing the paths of overflows of the Green * land-Iceland-Scotland Ridge. Water flowing northward past Iberia is AABW.

Strait, forming NADW. The combined flow around Greenland and into the Labrador Sea is estimated to be about $10 \mathrm{~Sv}$ (Warren 1981).

Deep water formed by ocean convection in the Labrador Sea flows into the Western North Atlantic Basin, overriding the Greenland-Scotia ridge overflow waters as middle NADW. Outflow of saline water from the Mediterranean spreads in the Central and North Atlantic at depths of 1000 to $1500 \mathrm{~m}$, and is termed Mediterranean Water or Upper NADW (Kellogg 1987). Mixtures of all of these waters form North Atlantic Deep Water.

\section{KNOWN PERTURBATIONS OF DEEP WATER PRODUCTION}

\section{The Great Salinity Anomaly}

A modern example of the delicate balance of the thermohaline circulation occurred in the late 1960s, 1970s, and early 1980s during an event that has 
come to be known as the Great Salinity Anomaly, described by Dickson et al (1988).

In 1962 the Denmark Strait Overflow Water (DSOW) had the "normal" temperatures and salinities cited above. However, from 1965 to 1971 extremely heavy ice conditions developed in the sea around Iceland. These severe ice years were characterized by abnormally low surface salinities believed to be advected into the area from the northwest. As the salinity decreased below $34.7 \%$, winter overturning of the surface water column ceased. With the lack of convective overturn, advection of fresher waters further freshened the surface. The low salinity surface waters became incorporated into the southward flowing East Greenland Current. In the Labrador Sea, the salinity decrease reached a threshold in 1968, when yearround salinity stratification developed, preventing the production of Labrador Sea Deep Water. The near surface salinity fell to $34.4 \%$ and convection was limited to the upper $200 \mathrm{~m}$ (Lazier 1980). The minimum salinities were reached in the Labrador Sea in 1972, whereupon the salinity began to increase again.

Entering the system of eastward flow across the North Atlantic, the salinity anomaly spread across the Subarctic Convergence, the northern boundary of the North Atlantic Current. Dickson et al (1988) attributed this to interactions between the Gulf Stream System and the slope water south and east of Flemish Cap. In 1972, the number of icebergs drifting south of $48^{\circ} \mathrm{N}$ was the largest ever recorded, and the iceberg season was the longest on record (Wolford 1982).

By 1975 the salinity anomaly had reached the eastern side of the North Atlantic, off Ireland, whereupon it split, part going south with the Canaries Current and passing Iberia in 1977, and part flowing north into the Norwegian Sea. The anomaly crossed the Iceland Faroes Ridge in 1976, reached the Barents Sea in 1978, and passed back into the Arctic Basin in 1979 (Dickson et al 1988).

The rate of deep water formation in the Greenland Sea was reduced in the 1980s, starting sometime between 1978 and 1982 (Schlosser et al 1991). Although the cause is uncertain, it may be related to the return of the freshened waters of the Great Salinity Anomaly to this area.

At its maximum in the Labrador Sea the salinity anomaly represented a salt deficit of $72 \times 10^{9}$ tons; on its return across the Iceland Faroes Ridge, it represented a deficit of $47 \times 10^{9}$ tons. Pollard \& Pu (1985) advocated in situ freshening as an explanation of the salinity anomaly, but calculated that by 1977 the freshening was equivalent to a layer of fresh water $1.4 \mathrm{~m}$ thick having been added to the surface of the Eastern Atlantic. Equivalent to an addition of $0.16 \mathrm{~m}$ of fresh water per year for each of the nine years from 1967-1976, this would require a $20-30 \%$ increase in precipitation or 
reduction in evaporation, which was not observed. They noted that the salinity anomaly freshened a large volume of ocean water and wondered where the ocean had become saltier. Dickson et al (1988) suggested an alternative: the advection hypothesis. They proposed that the freshening occurred as a result of enhanced sea ice formation in the high Arctic. The sea ice formation transferred the salt that had been brought into the region by northward flowing currents entering the Norwegian Sea into the intermediate and deep waters, freshening the surface waters and providing an excess of low salinity polar surface water for export into the Atlantic. Alternatively, they suggest that the salinity anomaly might have been caused by increased southward transport of polar water under strong winds during the 1960s.

The climatic effects of short-term (decadal to centennial) changes in sea surface temperature associated with the El Niño and the Southern Oscillation (ENSO) (a tropical phenomenon which influences the climate into the subtropics and perhaps beyond) have been demonstrated (Rasmussen 1985, Folland et al 1986, Flohn 1987, Philander 1989, Peixoto \& Oort 1992). There is less information about the effects of short-term changes ii. sea surface temperature at high latitude associated with salinity anomalies and deep water production, and the climatic effect of the passages of the Great Salinity Anomaly have not been directly documented. Newell \& Hsiung (1987) have discussed the relation between changes of sea surface temperatures (SSTs), free air temperatures, and precipitation for 19491979. They noted that the main variability of SST and air temperatures is associated with El Niño. However, they divided the SST eigenvector analysis into two periods, 1949-1964 and 1965-1979, which have been characterized as "wet" and "dry" or warmer and cooler respectively, with the latter period being associated with the Sahel drought. The latter of these periods corresponds to the life of the Great Salinity Anomaly. It is not known whether the change in climate caused the Great Salinity Anomaly or vice versa. Zonal westerly winds over the North Atlantic were stronger during the first period. This should have resulted in Ekman transport of cooler high latitude waters to the south and greater evaporation over the ocean surface, but these were the warm years for SSTs in the North Atlantic. It may be that the cooling of the North Atlantic and onset of dryer conditions might be related to the salinity anomaly and advection of fresher cooler waters into the North Atlantic.

\section{The Younger Dryas Cooling Event}

Much of the discussion about the climatic effects of changes in polar deep water production has centered on seeking explanation for the Younger Dryas cooling episode that affected the North Atlantic (Ruddimann \& 
McIntyre 1981) and surrounding land areas (Mercer 1969, Mangerud et al 1974, Mangerud 1987) from 11,000 to $10,000{ }^{14} \mathrm{C}$ years B.P. $[=13,000$ 11,700 calendar years B.P. according to Fairbanks (1990)]. Prior to the Younger Dryas the climate of northern Europe had become much like it is today. The cooling of summer temperatures experienced in northern Europe during the Younger Dryas was in the order of $5-6^{\circ} \mathrm{C}$. In western Norway the mean annual temperature declined by $13^{\circ} \mathrm{C}$. This climate change occurred within one or two centuries (Flohn 1986).

Kennett (1990) has reviewed the state of knowledge of conditions during the Younger Dryas and discussed some possible causes. The immediate cause is generally agreed to be a relocation of the North Atlantic Current to its glacial position. During the last glacial pcriod it flowed east at about $45^{\circ} \mathrm{N}$ (McIntyre et al 1976). Its nothern edge marked the boundary between the open Central Atlantic Ocean and ice-covered North Atlantic. Perennial ice cover would inhibit deep water formation by insulating the ocean from the influence of the atmosphere. Prior to the Younger Dryas the North Atlantic Current flowed northward into the Norwegian Sea although it was not as strong as it is today (Jansen 1987). The climatic changes that occurred in northern Europe during the Younger Dryas are well explained by assuming that the North Atlantic Current returned to its glacial position.

Why did this change occur? Fresh water outflow through the St. Lawrence increased as the glacial drainage systems became reorganized (Broecker et al 1988). Teller (1990) analyzed the changes in runoff from the Laurentide ice sheet before, during, and after the Younger Dryas. The runoff from the southern side of the ice sheet was concentrated into the Mississippi drainage prior to the Younger Dryas. At about 11,000 B.P. the ice retreat exposed a passage between Lake Aggasiz on the southwest side of the ice sheet, and the Great Lakes (Broecker ct al 1989). This allowed the major part of the southern drainage to be diverted around the southern margin of the ice and to the northeast, into the St. Lawrence valley. Teller estimates the earlier St. Lawrence outflow to have been about $900 \mathrm{~km}^{3} \mathrm{yr}^{-1}$. The additional meltwater increased this flow to $1730 \mathrm{~km}^{3}$ $\mathrm{yr}^{-1}$ during the Younger Dryas. The connection from Lake Agassiz into the Great Lakes region was subsequently severed by the Marquette readvance of the ice, which returned flow to the Mississippi. Broecker \& Denton (1989) have assumed that this would freshen the surface of the North Atlantic sufficiently to turn off the production of deep water-a conclusion supported by ocean model studies (Maier-Reimer \& Mikolajewicz 1989). The increment during the Younger Dryas amounts to a thickness of $0.16 \mathrm{~m} \mathrm{yr}^{-1}$ over the North Atlantic between $45^{\circ}$ and $60^{\circ} \mathrm{N}$. This is the amount that Pollard \& Pu (1985) reckoned to be required to 
produce the Great Salinity Anomaly as observed in the eastern North Atlantic. The higher inflow during the Younger Dryas lasted a thousand years whereas that associated with the Great Salinity Anomaly lasted less than a decade.

Sources other than the increased meltwater outflow through the St. Lawrence have been suggested as potentially significant supplies of fresh water. Miller \& Kaufman (1990) suggest that the entry of warmer waters into the Labrador Sea resulted in large-scale calving of icebergs. Another mechanism by which the cessation of North Atlantic Deep Water formation during the Younger Dryas may have affected climate is by altering the $\mathrm{CO}_{2}$ content of the atmosphere, as will be discussed below. Stauffer et al (1984) described a decrease in the $\mathrm{CO}_{2}$ content of the air trapped in the Dye 3 ice core from Greenland during the Younger Dryas, although they noted that melting may have affected the record.

\section{The Glacial-Interglacial Record}

During the last glacial maximum, the polar oceans had more extensive sea ice cover than they do at present. Most of the present areas of deep and bottom water formation were covered by perennial sea ice. Kellogg (1987) has discussed the possible sites and modes of deep water formation during the last glacial maximum. The lowered sea level $(\sim 130 \mathrm{~m})$ greatly reduced the area of continental shelvesavailable as sites for deep water formation. It is clear that the different climate of the glacial maximum would profoundly affect deep water formation, but it is not clear whether the changes in deep water formation would significantly affect the ice-age climate.

A decade ago it was discovcred that the atmospheric $\mathrm{CO}_{2}$ content during the last glacial maximum was about $80 \mathrm{ppm}$ less than its modern preindustrial level (Berner et al 1979, Delmas et al 1980, Neftel et al 1982). Then it was discovered that rapid variations (a few hundred years) of the atmospheric $\mathrm{CO}_{2}$ level were recorded in ice cores (Stauffer et al 1984). The hypotheses that had been suggested to explain the long-term glacialinterglacial changes in atmospheric $\mathrm{CO}_{2}$, such as alternating sequestering and resupply of nutrients to the ocean from the continental shelves with sea level change (Broecker 1981), the coral reef buildup hypothesis of Berger (1982), the change in the Redfield ratio originally suggested by Weyl (1968), the denitrification and model of Berger \& Kier (1984), and the change in rain rate of organic and inorganic carbon of Berger \& Kier (1984) all have long time constants and cannot explain short-term fluctuations of the magnitude observed. A consensus has arisen that the answer must lie in changes in ocean circulation.

Oeschger et al (1984) noted that phosphate and presumably other nutrients are not depleted in waters where active upwelling and overturning 
takes place. They cited equatorial Pacific waters as having an available ("preformed") phosphate content of $20 \%$ of the deep sea value and Antarctic waters as having a preformed phosphate content $70 \%$ that of deep water. They argue that biological productivity in these areas is not limited by the availability of the nutrients, but is controlled by the rate of convection of the water. They estimate that complete depletion of the phosphate in the surface waters of the ocean would reduce atmospheric $\mathrm{CO}_{2}$ from $300 \mathrm{ppm}$ to $200 \mathrm{ppm}$. They suggest that if the ocean changed from a relatively stagnant state to one with vigorous themohaline circulation, this would result in a situation where the nutrients brought to the surface could no longer be fully utilized, resulting in higher $\Sigma \mathrm{CO}_{2}$ in the surface waters and feeding $\mathrm{CO}_{2}$ into the atmosphere. A shutdown in deep water formation implics a lowercd level of atmospheric $\mathrm{CO}_{2}$ and intensive thermohaline circulation implies higher levels of atmospheric $\mathrm{CO}_{2}$.

Broecker \& Takahashi (1984) explored the behavior of ocean box models, each with an atmosphere, a warm surface ocean reservoir, and a deep ocean reservoir in communication with the atmosphere and laterally with the warm ocean reservoir at high latitudes. They considered the differences between two different types of model: $(a)$ a Thermodynamic Ocean, in which the $\mathrm{CO}_{2}$ exchange is dependent only on the temperature differences between the reservoirs and $(b)$ a Redfield Ocean, where the atmospheric transport of $\mathrm{CO}_{2}$ is assumed to be ineffective, and the differences in $\Sigma \mathrm{CO}_{2}$ are assumed to be strictly driven by lateral exchange of water between the warm and cold oceans and by the organic particle fluxes from the warm surface ocean to the deep sea. They conclude that changing the transfer rate between the warm and cold water reservoirs causes the introduction of nutrients and "biological pumping" of carbon from the warm reservoir into the deep sea. They calculated that a significant increase in transfer of water between the warm and cold reservoirs would result in a lowering of atmospheric $\mathrm{CO}_{2}$ to glacial maximum levels.

Sarmiento \& Toggweiler (1984) provided a quantitative model with boxes to represent the atmosphere, low-latitude and high-latitude surface oceans, and the deep ocean. They emphasize the importance of complete use of nutrients upwelled into the low-latitude ocean contrasted with only partial use of the nutrients upwelled into the high-latitude ocean. Their model demonstrates the importance of high-latitude ocean convection in controlling atmospheric $\mathrm{CO}_{2}$ levels. They note that at present the upwelling subpolar cyclonic gyres (within which deep water formation must take place) are centered on $60^{\circ}$ latitude, at the edge of polar night. They suggest that during the glacial maximums these were displaced equatorward, into regions where they received more light, enhancing the growth of phytoplankton. 
Siegenthaler \& Wenk (1984) have designed a different four box model with atmosphere, warm and cold surface oceans, and a deep ocean. They note that the $\Sigma \mathrm{CO}_{2}$ of surface seawater is $10 \%$ to $20 \%$ lower than that of deep water because of the continuous removal of carbon by organisms and the subsequent organic particulate flux to the deep sea. Broecker (1981) had suggested that during times of lowered sea level (glacials) the ocean receives an extra supply of nutrients from the erosion of the exposed continental shelves. This increased nutrient supply raised the overall ocean nutrient content and this allowed the contrast between $\Sigma \mathrm{CO}_{2}$ in the surface and deep waters to increase, effectively depleting surface water $\mathrm{CO}_{2}$ and lowering atmospheric $\mathrm{CO}_{2}$. They note that this process would require thousands of years to be effective, and although this might explain the long-term trends between glacials and interglacials it cannot explain the short-term variations observed in ice cores. For their standard case, assumed to mimic the present condition, they found a global upwelling flux of $15 \mathrm{~Sv}$ and an equal Antarctic deep water formation rate. They assume an Antarctic vertical convection rate of $44 \mathrm{~Sv}$. This produces an atmospheric $\mathrm{CO}_{2}$ concentration of $282 \mathrm{ppm}$. If the rate of vertical convection in the Antarctic is reduced by $50 \%$ to $22 \mathrm{~Sv}$, while assuming the organic particulate rain rate to remain constant, the surface $\Sigma \mathrm{CO}_{2}$ and atmospheric $\mathrm{CO}_{2}$ are reduced, the latter by $52 \mathrm{ppm}$. They also experimented with a change in the rate of upwelling/deep water formation, doubling it to $30 \mathrm{~Sv}$. This results in a decrease of atmospheric $\mathrm{CO}_{2}$ by 25 $\mathrm{ppm}$. The enhanced low-latitude upwelling results in a greater particulate flux to the deep sea. In this case increasing the rate of global thermohaline circulation results in a decrease of atmospheric $\mathrm{CO}_{2}$. It must be borne in mind that all of these models are gross simplifications of the circulation of the real ocean. They include only deep water formation and do not include formation of intermediate waters that are directly involved in lowlatitude upwelling.

\section{THE CONVEYOR BELT}

Broecker et al (1985) have suggested that the global thermohaline circulation system can be thought of as a conveyor belt (Figure 7). The largescale circulation of water in the deep sea is reflected in the distribution of $\mathrm{PO}_{4}, \mathrm{NO}_{3}, \mathrm{Ba}$, dissolved $\mathrm{SiO}_{2}, \Sigma \mathrm{CO}_{2}$, alkalinity, and $\mathrm{O}_{2}$ in the deep waters (Broecker \& Peng 1982). All of these, except $\mathrm{O}_{2}$, have their lowest concentrations in the North Atlantic and their highest concentrations in the North Pacific, with intermediate values in the South Atlantic, Indian, and South Pacific Oceans. The concentration of $\mathrm{O}_{2}$ is the reverse. Oxygen is consumed as organic particulate material is decomposed in the deep 


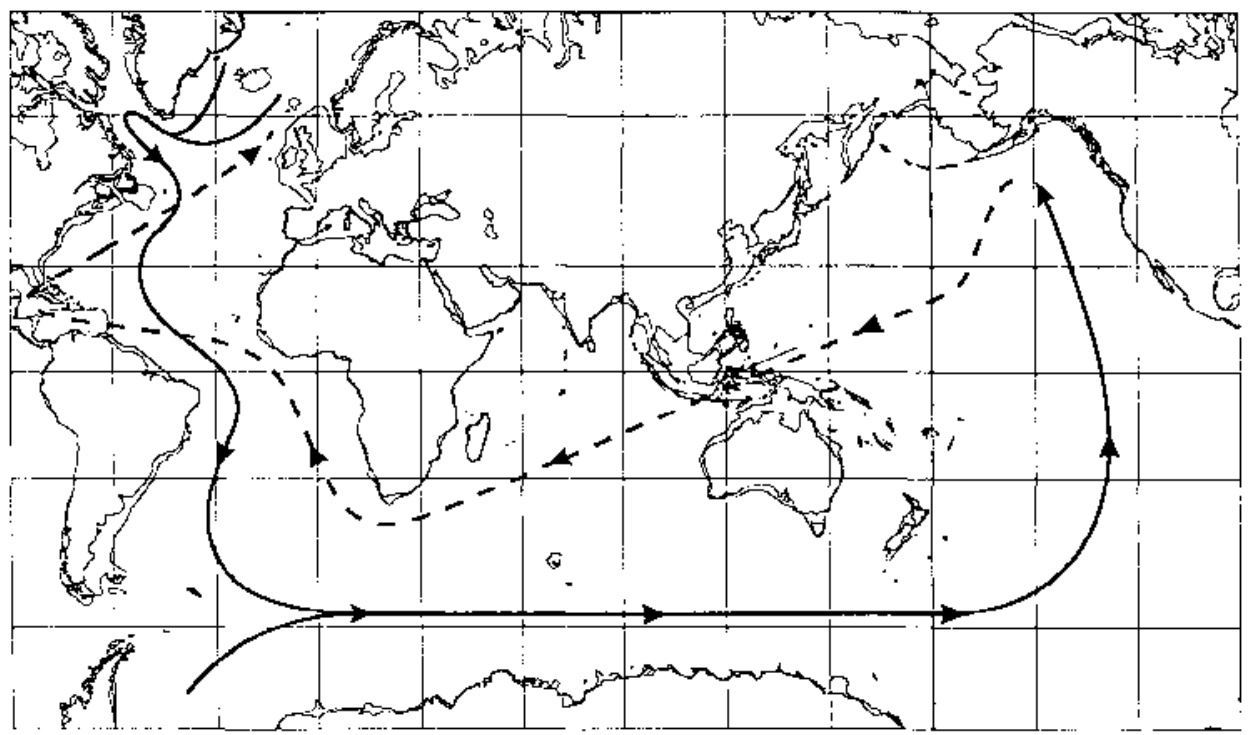

Figure 7 The "conveyor belt" of Broecker et al (1985). Deep transport shown by solid arrows and the very generalized surface transport by dashed arrows.

sea, releasing the other constituents. The concentration gradients are a reflection of the age of the water since it left the surface. It is suggested that the water that sinks in the GIN Sea flows southward through the deep Atlantic to the Southern Ocean, where it mixes with water sinking in the Weddell Sea. It then flows across the Indian Ocean, passes south of Australia, enters the South Pacific and finally reaches the North Pacific. Along the route water upwells to the surface and follows a return path from the Pacific through the Southeast Asian Seas, across the Indian Ocean, around the tip of Africa, and north through the Atlantic to the GIN Sea. Gordon (1986) has discussed this global circulation scheme showing that the return flow takes place both through surface currents and in the thermocline. The transfer of warm water from the Indian Ocean to the South Atlantic via the Agulhas Current makes a significant contribution to the northward meridional heat flux of the Atlantic, and thus a direct impact on the regional climate. They argue that the hypotheses requiring reduced nutrients in high-latitude waters to achieve the lower glacial levels of $\mathrm{CO}_{2}$ in the atmosphere are not supported by geochemical evidence which indicates that the surface waters during the glacial were 
not nutrient depleted. They believe that the $\mathrm{Cd} / \mathrm{Ca}$ nutrient proxy data of Boyle \& Keigwin (1982) provide compelling evidence that the production of deep water in the North Atlantic was greatly reduced. Subsequent studies offer additional support (Boyle 1988, 1992).

Broecker et al (1985) report the results of an atmospheric General Circulation Model (GCM) with present-day ocean temperatures everywhere except in the North Atlantic, where they used glacial (18 ka) temperatures of CLIMAP (1981). They believe the results to be consistent with the climatic data for the Younger Dryas in the North Atlantic region. They speculate on the possibility that if one aspect of the reduction of North Atlantic deep water formation is a lowered salinity of the surface water, the opposite might be true for the North Pacific. If this were the case, then the global thermohaline circulation system might reverse, with deep water formation taking place in the North Pacific and the deep North Atlantic becoming the site of concentration of nutrients.

The St. Lawrence meltwater diversion hypothesis has been called into question by Fairbanks (1989) who noted that sea level rose more rapidly both before and after than during the Younger Dryas. Taking this into account, Broecker et al (1990) have suggested that the conveyor belt may have an internal oscillation built in. They suggest that when the conveyor is turned on (NADW is being produced) the introduction of warm waters to high latitudes causes the ice sheets surrounding the North Atlantic to retreat. The running conveyor belt continuously exports salt from the North Atlantic. The export of salt, along with the inflow of meltwater, causes the salinity of the North Atlantic to decrease. When the system becomes delicately balanced, a meltwater diversion can cause the conveyor to stop (NADW production ceases). This reduces the meridional heat flux to the North Atlantic and the salt export. The ice sheet retreat slows or stops, reducing the meltwater input. As vapor transport to the Pacific continues, the salinity again rises until the conveyor starts again. These ideas have been further developed and explored by Broecker $(1989,1990)$, Broecker et al (1990), Birchfield \& Broecker (1990), and Birchfield et al (1990).

Ocean modelers have shown that multiple states of the thermohaline circulation system are possible. Marotzke \& Willebrand (1991) used a general circulation model with two idealized oceans of equal size extending north from a southern circumglobal seaway and separated by two continents of equal size. They found that the easiest to achieve condition was one with sinking in the north in both oceans. They initially perturbed the system by increasing the evaporation over the "Atlantic" by $0.18 \mathrm{~m} \mathrm{yr}^{-1}$ and increasing the precipitation over the Pacific by an equal amount, thereby reproducing the conveyor belt. By reversing these conditions they 
could reverse the conveyor belt. They also found that by initially decreasing the salinities in the north by $0.5 \%$ o the model could be forced to a condition where sinking took place only in the south. Stocker \& Wright (1991) have used a model with two zonally averaged basins representing the Atlantic and Pacific. They found that with an Atlantic to Pacific fresh water flux of $0.3 \mathrm{~Sv}$, the conveyor belt was maintained, and that it was insensitive to changes until the interocean vapor transfer was reduced to $0.03 \mathrm{~Sv}$, whereupon it stopped. In this state deep water formation took place only in the south.

\section{WHEN AND WHERE DID POLAR DEEP WATER FORMATION BEGIN?}

Hay (1988) presented a general review of paleoceanography. A variety of evidence suggests that polar oceans were warm during the Mesozoic, and that the cooling began in the early Cenozoic. A chilling of deep water occurred in the South Atlantic at the end of the Paleocene, and the ocean basins began to fill with cooler and cold waters at the end of the Eocene. The Weddell Sea has long had the appropriate shape and position to be a source of cold deep watcrs, but very little is known about the sources that must have existed in other parts of the world. The GIN Sea, which plays such an important role in NADW production today, had shallow, narrow connections with the North Atlantic until $10 \mathrm{Ma}$ (Thiede \& Eldholm 1983). Much more will have to be known about the paleogeography of the continental shelves and the connections between marginal seas and the ocean basins before ancient sites of polar and subtropical deep water formation can be determined.

\section{ACKNOWLEDGMENTS}

The author is indebted to Tom Rossby and Michael Schulz who reviewed drafts of the manuscript. This review was written while the author was a Senior Research Scientist and Gastprofessor at GEOMAR, Kiel, FRG, under the auspices of the Alexander Von Humboldt Foundation.

\section{Literature Cited}

Aagaard, K. 1981. On the deep circulation in the Arctic Ocean. Deep-Sea Res. 29: $251-68$

Aagaard, K., Swift, J. H., Carmack, E. C. 1985. Thermohaline circulation in the Arctic Meditcrranean Seas. J. Geophys. Res. 90: 4833-46

Alyushinskaya, N. M., Ivanov, V. V. 1978.
Water inflow from land. In World Water Balance and Water Resources of the Earth, ed. V. I. Korzun, pp. 568-74. UNESCO

Berger, W. H. 1982. Increase of carbon dioxide in the atmosphere during deglaciation: the coral reef hypothesis. Naturwissenschaften 69: 87-88

Berger, W. H., Kier, R. S. 1984. Glacial- 
Holocene changes in atmospheric $\mathrm{CO}_{2}$ and the deep sea record. See Hansen $\&$ Takahashi 1984, pp. 337-51

Berner, W., Stauffer, B., Oeschger, H. 1979. Past atmospheric composition and climate, gas parameters measured on ice cores. Nature 275: 53-55

Birchfield, G. E., Broecker, W. S. 1990. A salt oscillator in the glacial Atlantic? A "scale analysis" model. Paleoceanography 6: 835-44

Birchfield, G. E., Wang, H., Wyant, M. 1990. A bimodal climate response controlled by water vapor transport in a coupled oceanatmosphere box model. Paleoceanography 5: 383-95

Boyle, E. A. 1988. The role of vertical chemical fractionation in controlling late Quaternary atmospheric carbon dioxide. J. Geophys. Res. 93: 15,701-14

Boyle, E. A. 1992. Cadmium and $\delta^{13} \mathrm{C}$ paleochemical ocean distributions during the stage 2 glacial maximum. Annu. Rev. Earth Planet. Sci. 20: 245-87

Boyle, E. A., Keigwin, L. D. 1982. Deep circulation of the North Atlantic over the last 200,000 years: geological evidence. Science 218: 784-87

Brennecke, W. 1921. Die ozeanographischen Arbeiten der deutschen Antarktischen Expedition 1911-12. Arch. Dtsch. Seewarte 39: 1-214

Broecker, W. S. 1981. Glacial to interglacial changes in ocean and atmosphere chemistry. In Climatic Variations and Variability: Fact and Theories, ed. A. Berger, pp. 111 21. Dordrecht: Reidel

Broecker, W. S. 1989. The salinity contrast between the Atlantic and Pacific Oceans during glacial time. Paleoceanography 4: 207-12

Broecker, W. S. 1990. Salinity history of the northern Atlantic during the last deglaciation. Paleoceanography 5: 459-68

Broecker, W. S., Denton, G. H. 1989. The role of ocean-atmospherc rcorganizations in glacial cycles. Geochim. Cosmochim. Acta 53: 2465-2601

Broecker, W. S., Peng, T.-H. 1982. Tracers in the Sea. Palisades, NY: Eldigio. $690 \mathrm{pp}$.

Broecker, W. S., Takahashi, T. 1984. Is there a tie between atmospheric $\mathrm{CO}_{2}$ content and ocean circulation. See Hansen \& Takahashi 1984, pp. 314-36

Broecker, W. S., Peteet, D. M., Rind, D. 1985. Does the ocean-atmosphere system have more than one stable mode of operation? Nature 315: 21-26

Broecker, W. S., Andree, M., Wolfli, W., Oeschger, H., Bonani, G., et al. 1988. The chronology of the last deglaciation: Implications to the causc of the Younger Dryas Event. Paleoceanography 3: 1-19
Broecker, W. S., Kennett, J. P., Flower, B. P., Teller, J., Trumbore, S., et al. 1989. The routing of Laurentide ice-sheet meltwater during the Younger Dryas cold event. Nature 341: 318-21

Broecker, W. S., Bond, G., Klas, M. 1990. A salt oscillator in the glacial Atlantic? 1, The concept. Paleoceanography 5: 469-78

Carmack, E. C. 1990. Large-scale physical oceanography of the polar regions. In Polar Oceanography: Part A: Physical Science, ed. W. O. Smith, Jr., pp. 171-222. San Diego: Academic

Carmack, E. C., Foster, T. D. 1977. Water masses and circulation in the Weddell Sea. In Polar Oceans, ed. M. J. Dunbar, pp. 151-65. Calgary, Alta., Canada: Arctic Inst. North Am.

Carmack, E. C., Killworth, P. D. 1978. Formation and interleaving of water masses off Wilkes Land, Antarctica. Deep-Sea Res. 25: 357-69

Chamberlin, T. C. 1906. On a possible reversal of deep-sea circulation and its influence on geologic climates. J. Geol. 14: 363-73

Clarke, R. A., Gascard, J.-C. 1982. The formation of Labrador Sea Water. Part I: large scale processes. J. Phys. Oceanogr. 13: $1764-78$

CLIMAP Project Members 1981. Seasonal reconstruction of the Earth's surface at the last glacial maximum. In Geological Society of America Map and Chart, Series 36. Boulder, Colo.: Geol. Soc. Am.

Coachman, L. K., Aagaard, K. 1974. Physical oceanography of Arctic and Subarctic seas. In Marine Geology and Oceanography of the Arctic Seas, ed. Y. Herman, pp. 1-72. Berlin: Springer-Verlag

Delmas, R. J., Ascencio, J. M., Legrand, M. 1980. Polar ice evidence that atmospheric $\mathrm{CO}_{2} 20,000$ BP was $50 \%$ of present. Nature 284: 155-57

Dickson, R. R., Meincke, J., Malmberg, S.-A., Lee, A. J. 1988. The "Great Salinity Anomaly" in the northern North Atlantic 1968-1982. Progr. Oceanogr. 20: 103-51

Emiliani, C. 1954. Temperatures of Pacific bottom waters and polar superficial waters during the Tertiary. Science 119: 853-55

Emiliani, C., Edwards, G. 1953. Tertiary ocean bottom temperatures. Nature 171: 887-89

Fairbanks, R. G. 1989. A 17,000-year long glacio-eustatic sea level record: influence of glacial melting rates on the Younger Dryas event and deep-ocean circulation. Nature 342: 637-42

Fairbanks, R. G. 1990. The age and origin of the "Younger Dryas Climate Event" in Greenland ice cores. Paleoceanography 5: 937-48

Flohn, H. 1986. Singular events and catas- 
trophes now and in climatic history. Naturwis.senschaften 73: 136-49

Flohn, H. 1987. Air-sea interaction processes as models for abrupt climatic changes. In Abrupt Climatic Change, ed. W. H. Berger, L. D. Labeyrie, pp. 23-30. Dordrecht: Riedel

Fof onoff, N. P. 1956. Some properties of seawater influencing the formation of Antarctic Bottom Water. Deep-Sea Res. 4: 3235

Folland, C. K., Palmer, T. N., Parker, D. E. 1986. Sahel rainfall and worldwide sea temperatures 1901-85. Nature 320: 602-6

Foster, T. D. 1972. An analysis of the cabbeling instability in sea water. J. Phys. Oceanogr. 2: 294-301

Foster, T.D., Carmack, E. C. 1976. Frontal zone mixing and Antarctic Bottom Water formation in the southern Weddell Sea. Deep-Sea Res. 23: 301-17

Foster, T. D., Carmack, E. C. 1977. Antarctic Bottom Water formation in the Weddell Sea. In Polar Oceans, ed. M. J. Dunbar, pp. 167-77. Calgary, Alberta, Canada: Arctic Inst. North Am.

Gill, A. E. 1973. Circulation and bottom water production in the Weddell Sea. Deep-Sea Res. 28: 111-40

Gordon, A. L. 1978. Deep Antarctic convection west of Maude Rise. J. Phys. Oceanogr. 8: 600-12

Gordon, A. L. 1982. Weddell Sea deep water variability. J. Mar. Res. 40: 199-217 (Suppl.)

Gordon, A. L. 1986. Interocean exchange of thermocline water. J. Geophys. Res. 91: 5037-46

Gordon, A. L., Nowlin, W. D. 1978. The basin waters of the Bransfield Strait. $J$. Phys. Oceanogr. 8: 258-64

Gordon, A. L., Tchernia, P. 1972. Waters of the continental margin off Adélie Coast, Antarctica. In Antarctic Res. Ser., 19, Antarctic Oceanology II: The Australian-New Zealand Sector, ed. D. E. Hayes, pp. 5969. Washington, DC: Am. Geophys. Union

Gow, A. J., Tucker, W. B., III. 1990. Sea ice in the polar regions. In Polar Oceanography: Part A: Physical Science, ed. W. O. Smith, Jr., pp. 47-122. San Diego: Academic

Hakkinen, S. 1987. A coupled dynamicthermodynamic model of an ice-ocean system in the marginal ice zone. J. Geophys. Res. 92: 9469-78

Hansen, J. E., Takahashi, T., eds. 1984. Geophysical Monograph 29, Maurice Ewing Volume 5, Climate Processes and Climate Sensitivity. Washington, DC: Am. Geophys. Union

Hay, W. W. 1988. Paleoceanography: a review for the GSA Centennial. Geol. Soc. Am. Bull. 100: 1934-56

Hogg, N. G. 1973. The preconditioning phase of MEDOC 1969, II, Topographic effects. Dee p-Sea Res. 20: 449-59

Hsiung, J. 1985. Estimates of global oceanic meridional heat transport. J. Phys. Oceanogr. 15: 1405-13

Jacobs, S. S., Georgi, D. T. 1977. Observations of the southwest Indian/Antarctic Ocean. In $A$ Voyage of Discovery, ed. M. Angcl, pp. 43-84. Ncw York: Pergamon

Jansen, E. 1987. Rapid changes in the inflow of Atlantic water into the Norwegian Sea at the end of the last glaciation. Ir. Abrupt Climatic Change, ed. W. H. Berger, L. D. Labeyrie, pp. 299-310. Dordrecht: Riedel

Kellogg, T. B. 1987. Glacial-interglacial changes in global deepwater circulation. Paleoceanography 2: 259-71

Kennett, J. P. 1990. The Younger Dryas Cooling Event: an introduction. Paleoceanography 5: 891-95

Killworth, P. D. 1977. Some models of bottom water formation. In Polar Oceans, ed. M. J. Dunbar, pp. 179-89. Calgary, Alta., Canada: Arctic Inst. North Am.

Killworth, P. D. 1979. On "chimney" formations in the occan. J. Phys. Oceanogr. 9: $531-54$

Killworth, P. D. 1983. Deep convection in the world ocean. Rev. Geophys. Space Phys. 21: 1-26

Lazier, J. R. N. 1973. The renewal of Labrador-Sea Water. Deep-Sea Res. 20: 34153

Lazier, J. R. N. 1980. Oceanographic conditions at Ocean Weather Ship Bravo 1964-74. Atmosphere-Ocean 18: 227-38

Maier-Reimer, E., Mikolajewicz, V. 1989. Experiments with an OGCM on the cause of the Younger Dryas. In Oceanography, 1988, ed. A. Ayala-Castañares, W. Wooster, A. Yanez-Arancibia, pp. 87100. Mexico City: UNAM

Mangerud, J. 1987. The Alleröd/Younger Dryas boundary. In Abrupt Climatic Change, ed. W. H. Berger, L. D. Labeyrie, pp. 163-71. Dordrecht: Riedel

Mangerud, J., Anderson, S. T., Berglund, B. E., Donner, J. J. 1974. Quaternary stratigraphy of Norden, a proposal for terminology and classification. Boreas 3: 109-28

Marotzke, J., Willebrand, J. 1991. Multiple equilibria of the global thermohaline circulation. J. Phys. Oceanogr. 21: 137285

Martinson, D. G., Killworth, P. D., Gordon, A. L. 1981. A convective model for the Weddell polynya. J. Phys. Oceanogr. 11: 466-88

McIntyre, A., Kipp, N. G., Bé, A. W. H., 
Crowley, T., Kellogg, T. B., et al. 1976. Glacial North Atlantic 18,000 years ago: a CLIMAP reconstruction. Geol. Soc. Am. Mem. 145: 43-76

Meincke, J. 1983. The modern current regime across the Greenland-Scotland Ridge. In Structure and Development of the Greenland Scotland Ridge: New Methods and Concepts, ed. M. H. P. Bott, S. Saxov, M. Talwani, J. Thiede, pp. 63750. New York: Plenum

Melling, H., Lewis, E. L. 1982. Shelf drainage flows in the Beaufort Sea and their effect on the Arctic Ocean pycnocline. Deep-Sea Res. 29: 967-86

Mercer, J. H. 1969. The Alleröd oscillation: a European climatic anomaly. Arc. Alp. Res. 1: 227-34

Miller, G. H., Kaufman, D. S. 1990. Rapid fluctuations of the Laurentide ice sheet at the mouth of Hudson Strait: new evidence for ocean/ice-sheet interactions as a control on the Younger Dryas. Paleoceanography 5: 907-19

Mosby, H. 1934. The waters of the Atlantic Antarctic Ocean. Sci. Results Nor. Antarct. Exped. 1927-1928 1: 1-131

Neftel, A., Oeschger, H., Staffelbach, T., Stauffer, B. 1982. $\mathrm{CO}_{2}$ record in the Byrd ice core, $50,000-5,000$ years BP. Nature 331: $609-11$

Newell, R. E., Hsiung, J. 1987. Factors controlling the free air and ocean temperature of the last 30 years and extrapolation to the past. In Abrupt Climatic Change, ed. W. H. Berger, L. D. Labeyrie, pp. 67-87. Dordrecht: Riedel

Oeschger, H., Beer, J., Siegenthaler, U., Stauffer, B., Dansgaard, W., Langway, C. C. 1984. Late glacial climate history from ice cores. See Hansen \& Takahashi 1984, pp. 299-306

Peixoto, J. P., Oort, A. H. 1992. Physics of Climate. New York: Am. Inst. Physics. $520 \mathrm{pp}$.

Peterson, W. H. 1979. A steady state thermohaline convection model. $\mathrm{PhD}$ thesis. Rosenstiel School Mar. Atmos. Sci., Univ. Miami. 160 pp.

Peterson, W. H., Rooth, C. 1976. Formation and exchange of deep water in the Greenland and Norwegian seas. Deep-Sea Res. 23: $273-83$

Philander, S. G. H. 1989. El Niño, La Niña, and the Southern Oscillation. New York: Academic. 293 pp.

Pickard, G. L., Emery, W. J. 1990. Descriptive Physical Oceanography. Oxford: Pergamon. 320 pp.

Pollard, R. T., Pu, S. 1985. Structure and circulation of the upper Atlantic Ocean northeast of the Azores. Progr. Oceanogr. 14: 44362
Rasmussen, E. M. 1985. El Niño and variations in climate. Am. Sci. 73: 168-77

Reid, J. L. 1979. On the contribution of the Mediterranean Sea outflow to the Norwegian-Greenland Sea. Deep-Sea Res. 26: 1199-1223

Rooth, C. 1982. Hydrology and ocean circulation. Prog. Oceanogr. 11: 131-49

Ruddimann, W. F., McIntyre, A. 1981. The North Atlantic Ocean during the last deglaciation. Palaeogeogr. Palaeoclim. Palaeoecol. 35: 145-214

Rudels, B. 1989. Haline convection in the Greenland Sea. Deep-Sea Res. 37: 14911511

Sarmiento, J. L., Toggweiler, R. 1984. A new model for the role of the oceans in determining atmospheric $\mathrm{pCO}_{2}$. Nature 308: 621-24

Schlosser, P., Bönisch, G., Rhein, M., Bayer, R. 1991. Reduction of deepwater formation in the Greenland Sea during the 1980s: evidence from tracer data. Science 251: 1054-56

Seabrooke, J. M., Hufford, G. L., Elder, R. B. 1971. Formation of Antarctic bottom water in the Weddell Sea. J. Geophys. Res. 76: $2164-78$

Siegenthaler, U., Wenk, T. 1984. Rapid atmospheric $\mathrm{CO}_{2}$ variations and ocean circulation. Nature 308: 624-26

Stauffer, B., Hofer, H., Oeschger, H., Schwander, J. 1984. Atmospheric $\mathrm{CO}_{2}$ concentration during the last deglaciation. Ann. Glaciology 5: 160-64

Stocker, T. F., Wright, D. G. 1991. Rapid transitions of the ocean's deep circulation induced by changes in surface water fluxes. Nature 351: 729-32

Stommel, H. 1961. Thermohaline convection with two stable regimes of flow. Tellus 13: 224-38

Stommel, H. 1962. On the smallness of sinking regions in the ocean. Proc. Natl. Acad. Sci. USA 48: 766-72

Swift, J. H., Aagaard, K., Malmberg, S.-A. 1980. The contribution of the Denmark Strait overflow to the deep North Atlantic. Deep-Sea Res. 27: 29-42

Teller, J. T. 1990. Volume and routing of late-glacial runoff from the southern Laurentide Ice Sheet. Quat. Res. 34: 12-23

Thiede, J., Eldholm, O. 1983. Speculations about the paleodepth of the GreenlandScotland Ridge during late Mesozoic and Cenozoic times. In Structure and Development of the Greenland-Scotland Ridge, ed. M. H. P. Bott, S. Saxov, M. Talwani, J. Thiede, pp. 445-56. New York: Plenum

Thompson, Benjamin (Count Rumford). 1800. Essays, Political, Economical, and Philosophical. London

von Humboldt, A. 1814. Voyages aux 
Regions Equinoctales du Noveau Continent, fait en 1799-1804, 3 vols. Paris

Warren, B. A. 1981. Deep circulation of the world ocean. In Evolution of Physical Oceanography, ed. B. A. Warren, C. Wunsch, pp. 6-41. Cambridge, MA: MIT Press

Weyl, P. K. 1968. The role of the ocean in climatic change: a theory of the ice ages. Meterol. Monogr. 8: 37-62

Wolford, T. C. 1982. Sea ice and iceberg conditions, 1970-79. Northwest Atl. Fish. Organ. Sci. Counc. Stud. 5: 39-42

Worthington, L. V. 1970. The Norwegian Sea as a mediterranean basin. Deep-Sea Res. 17: 77-84 
Annual Review of Earth and Planetary Sciences
Volume 21,1993

\section{CONTENTS}

MaNY JoBS, Victor Vacquier 1

Petrology of the Mantle Transition Zone, Carl B. Agee 19

Planetary Lightning, $C . T$. Russell 43

Sediment Deposition from Turbidity Currents, Gerard $V$.

$\begin{array}{lr}\text { Middleton } & 89\end{array}$

OXYGEN ISOTOPES IN METEORITES, Robert $N$. Clayton 115

AcID RaIn, Owen P. Bricker and Karen C. Rice 151

Mantle and Slab Contribution in Arc Magmas, $C . J$. Hawkesworth, K. Gallagher, J. M. Hergt, and F. McDermott 175

Trends and Patterns of Phanerozoic Ichnofabric, Mary $L$. Droser and David J. Bottjer

The Role of Polar Deep Water Formation in Global Climate Change, William W. Hay

Matrices of Carbonaceous Chondrite Meteorites, Peter $R$. Buseck and Xin Hua

ACCRETION AND ERosion In SubduCtion Zones: The Role of Fluids, Xavier Le Pichon, Pierre Henry, and Siegfried Lallemant

The Scaling of Impact Processes in Planetary Sciences, $K$. $A$. Holsapple

Progress in the Experimental Study of Seismic Wave AtTENUATION, Ian Jackson

The Global Methane Cycle, Martin Wahlen

Terrestrial Volcanism in Space and Time, Tom Simkin

Precambrian History of the West Australian Craton and AdjaCENT OROGENS, John Myers

Understanding Planetary Rings, Larry $W$. Esposito

Impact Erosion of Terrestrial Planetary Atmospheres, Thomas J. Ahrens

INDEXES

Subject Index

Cumulative Index of Contributing Authors, Volumes 1-21

Cumulative Index of Chapter Titles, Volumes 1-21 